\title{
炭材内装ペレットの酸素含有ガス流中での加熱による 部分還元鉄生成の反応モデル
}

\author{
井口 義章* \\ Reaction Model for the Formation of Partially Reduced Iron by Heating Iron Ore-coal \\ Char Composite Pellet in Oxygen Bearing Gas Flow \\ Yoshiaki IGUCHI
}

\begin{abstract}
Synopsis : A basic research on the production of partially reduced iron by heating iron ore-coal char composite pellet was conducted by using a pellet in oxygen bearing gas flow. Oxygen in the reaction gas generates heat by combusting carbon to very efficiently compensate the heat consumed by the strongly endothermic reaction of carbon $\mathrm{C}+\mathrm{CO}_{2}=2 \mathrm{CO}$, while oxygen also re-oxidized reduced iron. A simple non-isothermal model for the reaction was made to simulate the very complicated phenomena. We approximated the reduction of iron oxides and the gasification of carbon to be of first-order one-step reaction, respectively. Further we assume that the shrinking-core model is applicable to the penetration of oxygen into the pellet under the diffusion limit of oxygen in the gas film and the re-oxidized product shell. By applying the reaction model, we succeeded in simulating the experimental results.
\end{abstract}

Key words: reaction model; reduced iron; coal; composite pellet; oxygen; reduction; gasification; re-oxidation; combustion; shrinking-core mode.

\section{1. 緒言}

現在，炭材内装ベレット加熱による，複数の還元鉄製造 プロセスが開発中である。一つは，(株）神戸製鋼所と米 国Midrex 社が開発中のFASTMET法 ${ }^{1.21}$ である。1 2 層並べ た石炭内装へレットを，上部空間で然料とベレットから発 生した石炭の揮発分，COガスを燃焼させ，主として放射 加熱する。急速昇温中と昇温後におけるペレットの反応速 度をそれぞれ一定とした反応モデルを作成して，反応速度 の数值シミュレーションを行っている3-5)。また，ベル ギーのC.R.M.が開発中の COMET 法(1)では層厚3.2 6.4 mm の粉鉄鉱石層を最上層にして粉炭層と交互に2ないし 3 層 づつ積み重ねたたで，層上部空間からの放射熱で $1573 \mathrm{~K}$ 程 度に加熱還元する。ペレットの造粒プロセスを省略でき， 反応終了後に不炭の兏分を分離できることが特徵である。 数值シミュレーションはなされていない。

一方，炭材内装ヘレットを不活性䨌囲気中あるいは自己 発生需囲気中で加熱したときの，酸化鉄の還元反応と炭材 のガス化反応の逐次連続的反応については多くの研究がな されている。Huanと $\mathrm{Lu}^{7)}$, Sunと $\mathrm{Lu}^{8 /}$ はドーナツ状容器に 充填した鉄鉱不と炭材の混合粉を外部から電気炉で加熱し て, 半径方向 5 点での温度と反応率分布を測定し, 数学モ デルによるシミュレーションを行った。

また，空気中で炭材内装ぺレットを加熱して部分還元鉄

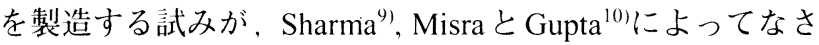

れている。彼らは，炭材内装の内核とそれを内装しない外 殻の 2 重構造ペレットを大気霉同気で加熱して内部で発牛: した COにより外㲄の酸化鉄をも一部還元して部分還元鉄 を製造することを試みた。しかし，試料は蓋付きルツボあ るいは一端封じの反応管内で加熱されており，空父との接 触状態は不明確で，定量的取扱いはなされていない

筆者は，炭材内装鉄鉱石へレットの酸素合有䨌㖀父中で の加熱による，部分還元鉄の製造を計画した，前献いで、 単一ペレットの同雲讲気加熱中における反応とそれに伴う 膨張率と压潰强度の変化について報告した。へレット中谈 素の燃焼熱をも利用した部分還元鉄製造フロセスの问能性: を検討するためには，反応と物質移動だけでなく问時に熱 の移動をも考慮して現象を定量的に取り扱わねばならな い。そのため反応モデルの作成が欠かせない，現象が複雑 なため，それを忠実に記述しようとすれば反志モデルが複 雑になる。しかし，反応プロセスの解析に生かすためには 簡単なモデルでなければならない。そこで本研究では，単 一炭材内装鉄鉣石ペレットの酸素含有需讲気中加熱による 還元鉄製造についての，単純な反応モデルの作成，その炎 験結果再現性，モデルによる諸条件の影響の検邻結果につ いて述べる。

\section{2. 試料調製と実験方法}

前報 ${ }^{11} に$ 記述したように，酸化鉄中の酸素と岸材中沽定 
炭素が等モルとなるように，粉鉄鉱石と 18.4 mass\%の チャーを混合し，さらに 1 mass\% (外量) のベントナイト と蒸留水を加えてタイヤ造粒機で造粒した。これらは乾燥 器で $378 \mathrm{~K} に 72 \mathrm{ks}$ 以上乾燥後使用した。

竪型炉で外部加熱された反応管中で白金線製のバスケッ トに乗せた 1 個ペレットを，室温に近い反応管上部の低温 部から所定最高温度部に $180 \mathrm{~s}$, 一部実験では $6 \mathrm{~s}$ で降下させ て急速加熱することによって反応させた。反応ガスは主と して $30 \% \mathrm{O}_{2}-\mathrm{N}_{2}$ 混合ガスを，内径 $29 \mathrm{~mm}$ の反応管に $35.5 \times 10^{-6} \mathrm{~m}^{3} / \mathrm{s}$ の流量で流した。また，熱天秤による重量 変化の連続測定, ペレットの中心と表面に埋込んだ素線径 $0.2 \mathrm{~mm}$ の白金熱電対による反応中温度の連続測定を行っ た。

反応終了後ペレットはX線回折を行い, $\mathrm{Fe}_{2} \mathrm{O}_{3}, \mathrm{Fe}_{3} \mathrm{O}_{4}$, $\mathrm{FeO}, \mathrm{Fe}$ の各相について, 内部標準法により含有率を計算 した。これから還元率を計算した。また，化学分析による $\mathrm{X}$ 線定量分析結果の検定, 燃焼法による炭素分析も行っ た。

\section{3. 反応モデルの作成}

炭材内装ペレット中では, 前報"1に記述した多くの反応 が逐次あるいは並行して進行する。ここでは, 反応速度式 を単純化するため，つぎの仮定のもとに反応モデルを作成 した。

1) 鉄鉱石粒子の還元反応, 炭素のガス化反応は均一反 応モデルで進行する。

2) ガス化反応

$\mathrm{C}(\mathrm{s})+\mathrm{CO}_{2}(\mathrm{~g})=2 \mathrm{CO}(\mathrm{g})$

の速度は，一次反応速度式で表わせる。

3 ) 酸化鉄の還元は( 2 )式

$\mathrm{Fe}_{2} \mathrm{O}_{3}+3 \mathrm{CO}=2 \mathrm{Fe}+3 \mathrm{CO}_{2}$

の一段反応で近似でき，一次反応速度式で表わせる。

4 ) 還元反応，ガス化反応は独立に進行する。

5 ) ペレット内の温度は均一である。

6 ）ペレット表面で対流伝熱と放射伝熱によって外界と の間で熱移動が起こる。

7 ) $\mathrm{O}$, の浸入によるペレットの再酸化は, 一界面未反応 核モデルによって表わされ，その速度は $\mathrm{O}_{2}$ のガス境 膜内物質移動，生成酸化物層内の拡散の律速である。

8 ) ペレット直径は一定で, 外殼部の再酸化物層は $\mathrm{Fe}_{2} \mathrm{O}_{3}$, 鉄鉱石中の脈石類, 炭材中の灰分から構成され, 内 核部は部分的に反応した鉄鉱石と炭材，少量の結合 骫から構成される。

9) 反応熱はすべて固体に与えられる。ペレット内部で 還元反応とガス化反応，ペレット表面部で $\mathrm{CO}$ の燃焼

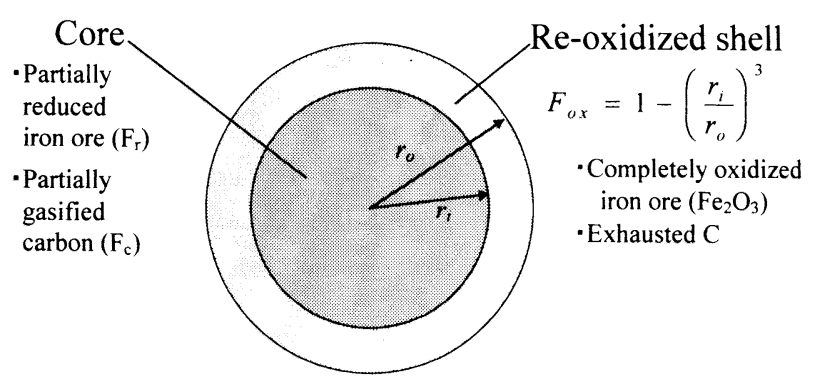

Fig. 1. Schematic illustration of a reaction model for simulating the reactions of an iron ore-coal char composite pellet in $\mathrm{O}_{2}-\mathrm{N}_{2}$ gas flow.

と還元生成物の再酸化反応が起こるので, 総括的に 還元についてはへマタイトの分解反応 3 )式，炭素の ガス化については燃焼反応 4 )式

$\mathrm{Fe}_{2} \mathrm{O}_{3}=2 \mathrm{Fe}+3 / 2 \mathrm{O}_{2} \quad \Delta H_{298}^{\circ}=821.3 \mathrm{~kJ} \cdot \mathrm{mol}^{-1} \ldots$

$\mathrm{C}+\mathrm{O}_{2}=\mathrm{CO}_{2}$

$\Delta H_{298}^{\circ}=-393.50 \mathrm{~kJ} \cdot \mathrm{mol}^{-1}$

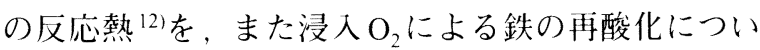

ては( 3 )式の逆反応を考慮して熱計算する。

反応が途中まで進行した状態を，上述の仮定に基づいて モデル化して Fig. 1に示した。核内部では，ガス化反応 (1)，還元反応 $(2)$ がそれぞれ独立に，反応率 $F_{c}, F_{r}$ まで進 行している。それらの速度は仮定 2), 3)に基づいて( 5 ), ( 6 )式で表わすことができる13.14)。

$$
\begin{aligned}
& d F_{c} / d t=k_{c}\left(1-F_{c}\right) \\
& d F_{,} / d t=k_{r}\left(1-F_{r}\right)
\end{aligned}
$$

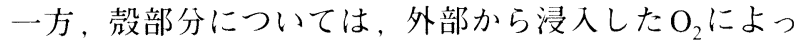
て, 残留炭素は燃焼して消滅し, 部分還元された鉄含有相 は $\mathrm{Fe}_{2} \mathrm{O}_{3}$ まで再酸化される。 $F_{\mathrm{ox}}$ の増加速度は，仮定7)に基 づき，さらに $1 \mathrm{~mol}\left(\mathrm{O}_{2}\right)$ が $2 \mathrm{~mol}(\mathrm{O})$ であることを考虑して， ( 7 )式15)で表わされる。

$$
\frac{d F_{\mathrm{ox}}}{d t}=\frac{6 C_{h} / r_{0}\left\{d_{c}\left(1-F_{c}\right)+d_{o} F_{r}\right\}}{1 / k_{\mathrm{g}}+r_{0}\left\{\left(1-F_{\mathrm{ox}}\right)^{-1 / 3}-1\right\} / D_{\iota}}
$$

一方，ペレットの温度はペレット表面における熱の移動 と反応熱によって変化し, ペレットの温度変化速度は(8) 式で表わされる。

$$
\begin{aligned}
\frac{d T_{s}}{d t}= & {\left[\begin{array}{c}
\frac{3 h}{r_{0}} \cdot\left(T_{h}-T_{s}\right)+d_{0}\left\{\left(1-F_{\mathrm{ox}}\right) \cdot \frac{d F_{r}}{d t}-F_{r} \cdot \frac{d F_{\mathrm{ox}}}{d t}\right\}\left(-\Delta H_{r}\right) \\
+d_{c} \cdot\left\{\left(1-F_{\mathrm{ox}}\right) \cdot \frac{d F_{c}}{d t}+\left(1-F_{c}\right) \cdot \frac{d F_{\mathrm{ox}}}{d t}\right\} \cdot\left(-\Delta H_{c}\right)
\end{array}\right] } \\
& \left\{\sum_{i} \rho_{i} \cdot\left(C_{p i}+T_{s} \cdot \frac{d C_{p i}}{d T_{s}}\right)\right\} \ldots \ldots \ldots \ldots \ldots \ldots \ldots \ldots \ldots \ldots \ldots \ldots \ldots \ldots \ldots \ldots \ldots
\end{aligned}
$$

ある時間における正味の還元率 $F_{r, \text { nct }}$, 炭素の全反応率 $F_{c, \text { total }}$ は, Fig. 1から直ちに(9),(10)式で表わされる。

$$
F_{r, \text { net }}=F_{r}\left(1-F_{\text {ox }}\right)
$$




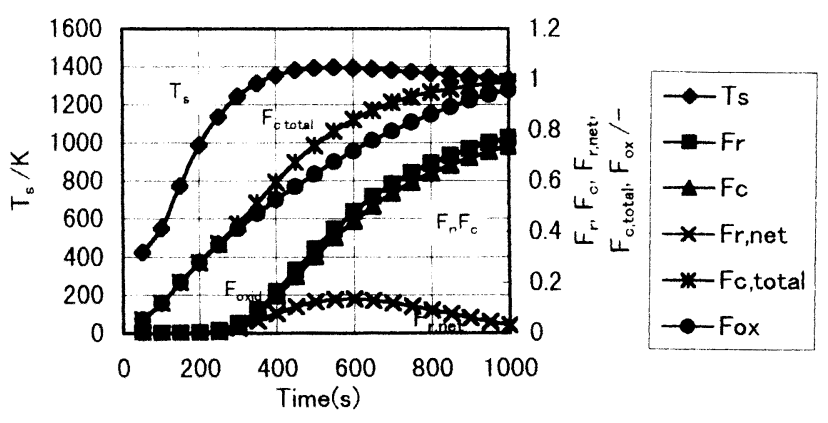

Fig. 2. Variation of the temperature and the various reaction extents of pellet while heating it in $30 \% \mathrm{O}_{2}-\mathrm{N}_{2}$ flow. The diameter of pellet, $d_{p}$, is $18 \mathrm{~mm}$ and the bulk temperature, $T_{h}$, is $1373 \mathrm{~K}$.

$$
F_{c \text { total }}=F_{\text {ox }}+F_{c\left(1-F_{\text {ox }}\right)}
$$

定数についてはつぎの俻を用いた。 $k_{r}, k_{r}$ の值は, 直径 $18 \mathrm{~mm}$ の炭材内装ベレットを用いて $\mathrm{N}_{2}$ ガス流中で実験的 に決定した(11),(12)式

$$
\begin{aligned}
& k_{r}=16.97 \exp \left(-12323 / T_{s}\right) \\
& k_{c}=19.24 \exp \left(-12632 / T_{s}\right)
\end{aligned}
$$

のArrhenius式を使用した。また，伝熱係数 $h$ は，Ranz Marshallの式 ${ }^{(6)}$ から㖕算した刘流伝熱係数 $h_{c}$ と, 反応管と ペレットとの同心円模型を考えた(13)式に基づいて計算し た放射伝熱係数 $h_{r}{ }^{17.18)}$ の和とした。(13)式で $\phi_{s i 1}$ は(14)式で 表わされる。 $D_{\iota}$ は，拡散率を 0.50 として，分子拡散係数 $D_{\mathrm{N} 2-\mathrm{O} 2}$ との積とした

$$
\begin{aligned}
& h_{r}=5.669 \phi_{s w}\left(T_{h}+T_{s}\right)\left(T_{h}^{2}+T_{s}^{2}\right) \times 10^{-8} \\
& \phi_{s w}=\varepsilon_{s} \cdot \varepsilon_{w} /\left\{\varepsilon_{w}+\left(d_{p} / D_{l}\right)^{2} \varepsilon_{s}\left(1-\varepsilon_{u}\right)\right\}
\end{aligned}
$$

その他，熱力学数値は, KnackeとAlcock ${ }^{12)} の$ 值を用いた。 ペレットを電気炉の最高温度部に降下させることによるぺ レット周井の温度变化は, 電気炉の温度分布の測定值を 使った

\section{4. モデルによる実験結果シミュレーションと 正味の還元率に及ぼす諸条件の影響につい ての検討}

ペレット直径 $18 \mathrm{~mm}$, バルク温度 $1373 \mathrm{~K}$, 酸素濃度 $30 \%$ $\mathrm{O}_{2}$, 拡散率 0.5 のときの, ペレット温度 $T_{s}$, 還元率 $F_{r}$, ガス化 率 $F_{c}$, 正味の還元率 $F_{r, \text { net }}$, 炭素の全反応率 $F_{c \text { ctotal }}$, 再酸化率 $F_{\text {ox }}$ の反応時間による変化を Fig. 2 に示す。拡散律速である $\mathrm{O}_{2}$ の浸入はペレット温度が低いときから進行して，炭素 の燃焼熱によって $T_{s}$ を上昇させる。温度がさらに上昇して 吸熱反応である炭素のガズ化反応が進み始めると $T_{\mathrm{s}}$ は下が り始める。温度が上がり $1300 \mathrm{~K}$ を超えると, 還元とガス化 が並行してかなり速い速度で進行する。二つの固体反応物 が近接して存在し， $\mathrm{CO}, \mathrm{CO}_{2}$ のガス分子を介して，反応が

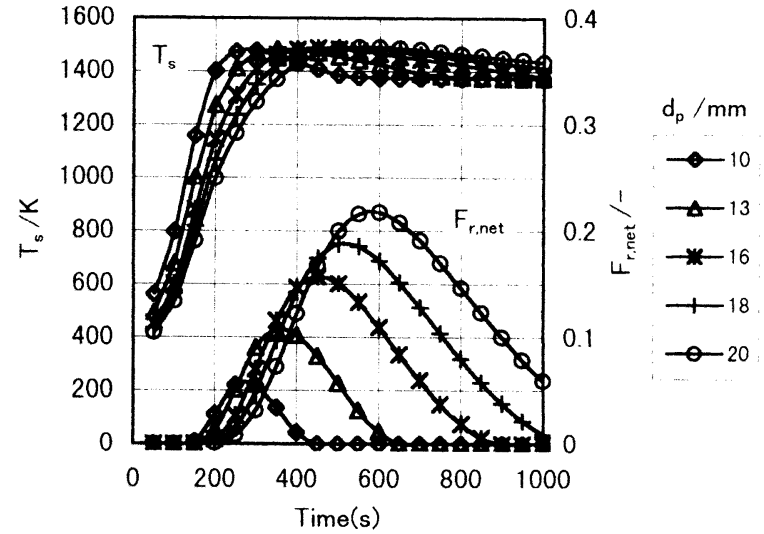

Fig. 3. Effect of the diameter of pellet on the temperature and net reduction degree while heating it in $30 \%$ $\mathrm{O}_{2}-\mathrm{N}_{2}$ flow. $T_{h}=1373 \mathrm{~K}$.

進行するためである。反応後半で网反応の速度が鈍ってく ると, 拡散律速で進行する再酸化の速度が勝り，Frnet は最 大值を経て 0 に向かって減少して行く。この条件で最大值 は約 0.18 で，前報の Fig. 3 に示した実験結果とほぼ...致し ている。しかし，最大となる反応時間は500sであり、へ レットの降下時間差を考慮した実験結果からの予想時間， $250+180-6=424 \mathrm{~s}$, よりやや遅れている。これはべレット 降下時に炉下部からの放射熱によりべレットの下部が，炊 の温度分布測定值よりも高温に加熱されるなどの理由によ ると推察される。反応率の変化では，ガス化と燃焼で並行 して炭素消滅反応が進行するので $F_{\text {c. total }}$ が最も速く1に到 達し，つづいて再酸化の $F_{\mathrm{ox}}$ が 1 に到達する。この条件で は $\mathrm{O}_{2}$ の浸入が勝り $F_{r}, F_{c}$ が 1 に到達する前に，炭素が消滅 して反応が終了する

$1373 \mathrm{~K}$ でペレット直径の影響を計算した結果をFig. 3 に 示した。ペレットが大きくなると体積/表面積の比， $r_{0}^{3} / 3 r_{o}^{2}$, が増し，還元優勢期間が長く続き， $F_{r . \text { net }}$ が大きくなるこ の傾向は実験結果とよく一致している。直径 $10 \mathrm{~mm}$ で最大 $F_{r, \text { net }}$ は約 0.06 で非常に小さいが, $20 \mathrm{~mm}$ で 0.22 である、 $T_{s}$ の最大值は約 $1500 \mathrm{~K}$ で大差ないが，r，が大きくなるほど高 温に保たれる時間が増す。

$30 \% \mathrm{O}_{2}, 18 \mathrm{~mm}$ での $T_{h}$ の影響を Fig. 4 に示す、高温ほど 短時間で最高の $T_{s}$ と最大の $F_{r, \text { net }}$ 值に到達する。指数関数 的に增大する $k_{r}, k_{c}$ の効果と推定される。これに対して再 酸化はガス拡散律速で温度上昇に対して相対的に増大が小 さい。しかし，実際には $T_{s} か ゙ 1600 \mathrm{~K}$ を超えると溶融するの で $T_{h}$ を $1573 \mathrm{~K}$ とする条件は採用できない。

$T_{h} 1373 \mathrm{~K}, 18 \mathrm{~mm}$ で $\mathrm{O}_{2} \%$ の影響を Fig. 5 に示した。 $\mathrm{O}_{2} \%$ が 小さいほどその浸入が弱く，還元期間が長く続き，最大の $F_{r, \text { net }}$ は大きくなる。その意味で $F_{r, \text { net }}$ に及ぼす $\mathrm{O}_{2} \%$ の影響 は非常に大きい。しかし温度差は意外に小さく，Tの最大 值は30Kしか違わない。反応初期だけを見れば，燃焼熱の ために $\mathrm{O}_{2} \%$ が大きいほどわずかながら還元率が高い。初 期の炭素燃焼反応による発熱のためである。フロセスに 


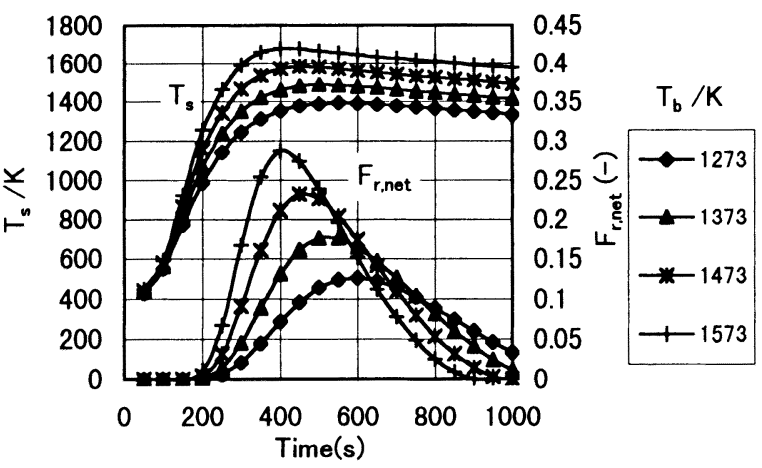

Fig. 4. Effect of the bulk temperature on the temperature and net reduction degree of pellet while heating it in $30 \% \mathrm{O}_{2}-\mathrm{N}_{2}$ flow. $d_{p}=18 \mathrm{~mm}$.

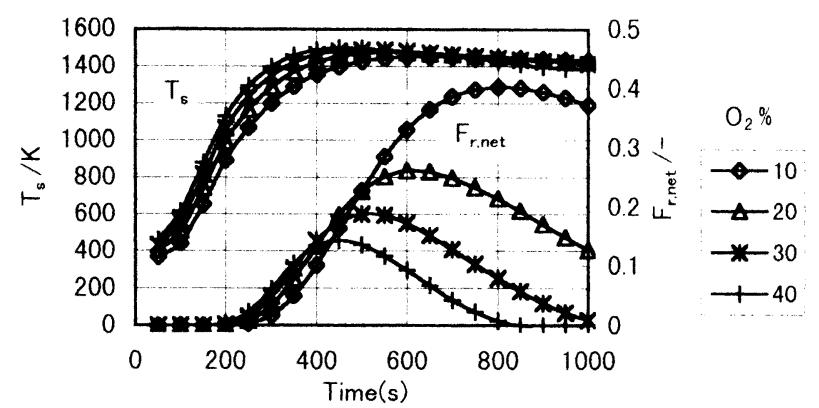

Fig. 5. Effect of the $\mathrm{O}_{2} \%$ on the temperature and net reduction degree of pellet while heating it in the flow of $\mathrm{O}_{2}-\mathrm{N}_{2}$ gas mixture. $T_{b}=1373 \mathrm{~K}, d_{p}=18 \mathrm{~mm}$.

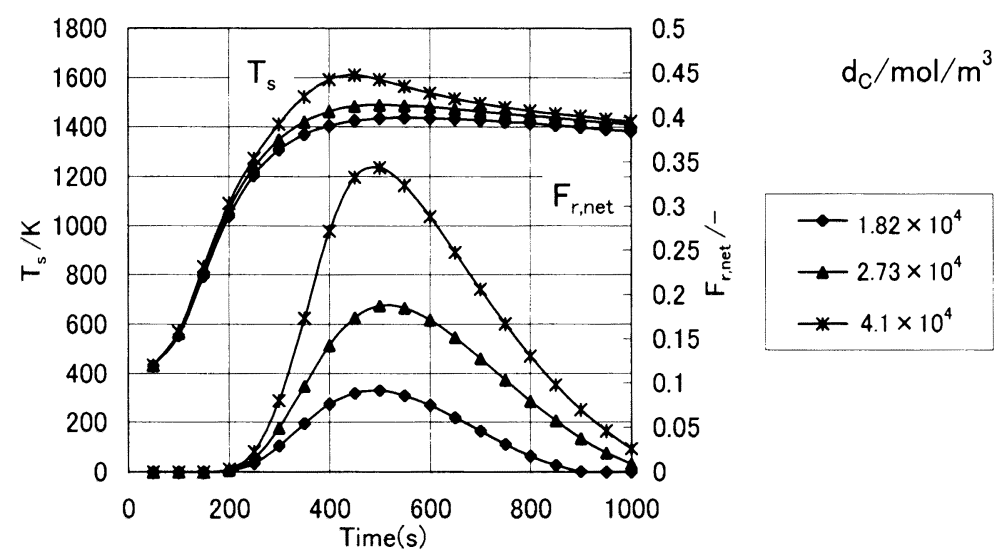

Fig. 6. Effect of the contents of mixed carbon on the temperature and net reduction degree of pellet while heating it in $30 \% \mathrm{O}_{2}-\mathrm{N}_{2}$ flow. $T_{b}=1373 \mathrm{~K}, d_{p}=18 \mathrm{~mm}$.

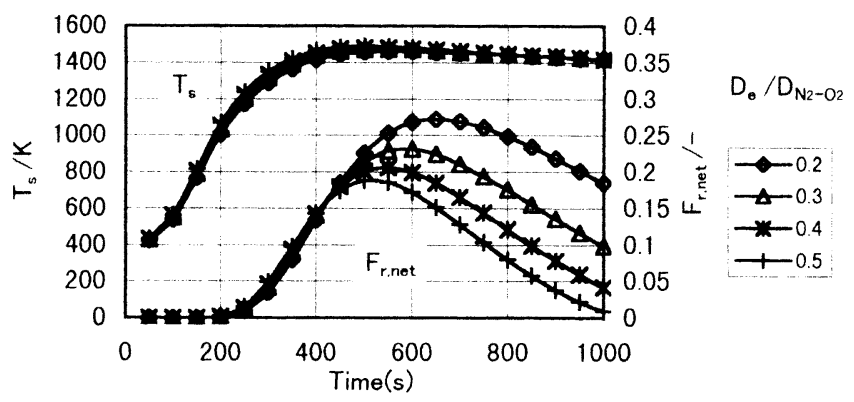

Fig. 7. Effect of the effective diffusivity of oxygen on the temperature and net reduction degree of pellet while heating it in $30 \% \mathrm{O}_{2}-\mathrm{N}_{2}$ flow. $T_{h}=1373 \mathrm{~K}$, $d_{p}=18 \mathrm{~mm}$.

\section{よっては高 $F_{r \text { net }}$ を得るのに利用できる。}

炭材の混合量を変えた結果をFig. 6に示した。18.4 mass \% $\left(2.73 \times 10^{4} \mathrm{~mol} / \mathrm{m}^{3}\right)$ を標準值として，その $2 / 3,1,3 / 2$ と $d_{c}$ を増すと, $F_{r \text {, net }}$ 值， $T_{s}$ ともに明確に大きくなる。炭素 が還元反応，温度上昇の両面で寄与した結果である。

ベレットを緻密にして気孔率を小さくしてやれば $\mathrm{O}_{2}$ の 浸入が妨げられて，Fr, net 拡散率を変化させて計算した結果をFig. 7に示す。拡散率 が大きくなっても，平均温度はほんのわずか増すだけであ る。しかし， $\mathrm{O}_{2}$ の浸入による再酸化が促進されて， $F_{r, \text { net }}$ は確実に小さくなる。

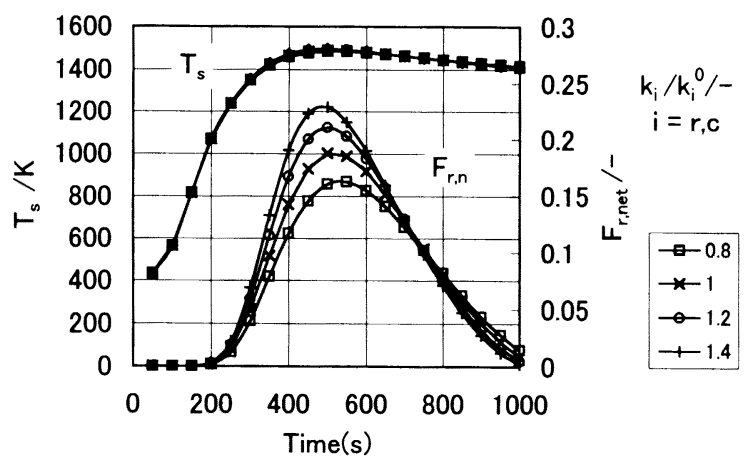

Fig. 8. Effect of the rates of reduction and gasification on the temperature and net reduction degree of pellet in $30 \% \mathrm{O}_{2}-\mathrm{N}_{2}$ flow. $T_{h}=1373 \mathrm{~K}, d_{p}=18 \mathrm{~mm}$.

炭材と鉄鉱石の反応性を増して， $k_{r}, k_{c}$ を大きくするのも 還元を促進するのに効果がある。Fig. 8 に示すように $T_{s}$ は ほとんど差がない。

\section{5. 反応モデルとシミュレーション結果の検討}

\section{$5 \cdot 1$ ペレット中でのガス流れ， $\mathrm{N}_{2}$ 浸入の影響}

3 に記述した反応モデルでは，ペレット内に打ける物質 移動でガス流れを無視した。ここで，反応によるガス分子 数の変化について考察する 
ベレットの内部に浸人した $\mathrm{O}_{2}$ は、まず内部からガス化 反応（1)で生成したCOを(15)式により燃焼する。残留した 岑素，還元鉄等の還元生成物と(4),(16)式で反応する。

$$
\mathrm{C}(\mathrm{s})+\mathrm{CO}_{2}(\mathrm{~g})=2 \mathrm{CO}(\mathrm{g}) \cdot
$$

$2 \mathrm{CO}(\mathrm{g})+\mathrm{O}_{2}(\mathrm{~g})=2 \mathrm{CO}_{2}(\mathrm{~g})$

$\mathrm{C}+\mathrm{O}_{2}=\mathrm{CO}_{2}$

$4 \mathrm{Fe}(\mathrm{s})+3 \mathrm{O}_{2}(\mathrm{~g})=2 \mathrm{Fe}_{2} \mathrm{O}_{3}(\mathrm{~s})$

内部の均一反応部分では(1)式でガス分子数が増加し, 外 部へ向けてのガス流れが生じる。一方, 外部から浸入した $\mathrm{O}_{2}$ 分子は(15), (4),(16)式により反応し, (4)式を除いてガ ス分子数は減少する。したがて, 反応初期に内部で(1) 式が活発なときは，再酸化物層内を外向きのガス流れがあ る。反応後半では(1)式に対して(4),(16)式が優勢となり, 内向きの流れがある。本論文では簡単のため, $\mathrm{O}_{2}$ 分子は ガス流れの影響を受けないとした。さらに子細に考察191す れば, 約 $1000 \mathrm{~K}$ 以上では, $(1)$ 式で生じたCOが外向きに 拡散して $\mathrm{O}_{2}$ と(15)式で $\mathrm{CO}$,を生じる。ここでは簡単のため 両式の総括反応 4 )式で単純化し, 未反応核モデルを適用 した。

また，反応ガス中 $\mathrm{N}_{2}$ がヘレットに浸入すれば、均一反 応での還元仪忍，ガス化反応の速度が( 5 ), ( 6 )式からずれ てくる可能性があるししし，両速度式が $N_{2}$ 中での測定 結果であり，両式が反応中終始適用できると近似した。

\section{$5 \cdot 2$ 単一ペレットによる反応特性}

Fig. 5 に示した $\mathrm{O}_{2}$ 分厌の影響を見ると、ペレットの最高

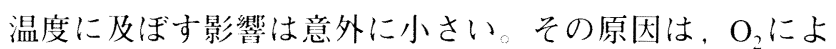
る酸化でヘレット温度が上昇してもその周囲温度が低いた め, 高温で非常に大きい放射伝熱による熱口スが大きくな る。しかし、ヘレットが充填状態にあれば $\mathrm{O}_{2}$ との反応に よる発熱が有効に利用できるはずである。

\section{6. 結言}

前報111で，粉鉄鉱不と不岑チャ一の混合ペレットを $\mathrm{O}_{2}$ 含有ガス流中に扎て㪀応させ，その結果を詳述した。本 報では, この応の数学モデルによるシミュレーション結 果を示した。還元反忍とガス化反応は, 均一反応モデルの 一次反応式で， $\mathrm{O}_{2}$ の浸入による再酸化はガス境膜内と再 酸化生成物層内のガス搪散律速の一界面未反応核モデル式 で表わし、ペレット内温度を均一として温度の時間变化を 考慮した反忘モデルを作成した。全般的に反応が $100 \mathrm{~s}$ 程 度長時間側にずれるが、このモデルにより実験結果をほぼ シミュレートすることができた。これに基づき, 最大正味 還元率に及ぼす温度, ペレット径、酸素分圧, 炭材濃度等 の影響を調べ，ほぼ験結果を再現することができた。こ のモデルによりベレット径を大きく，温度を溶融しない程 度に高くするのが有効であるとする実験結果を裏付けるこ
とができた。また、未実験あるいは実験が難しかった条件 では、シミュレーションにより混合する炭材量を多く、へ レットを緻密にすることにより，最大正味還元率を効果的 に増大できることが予測できた

\section{記号}

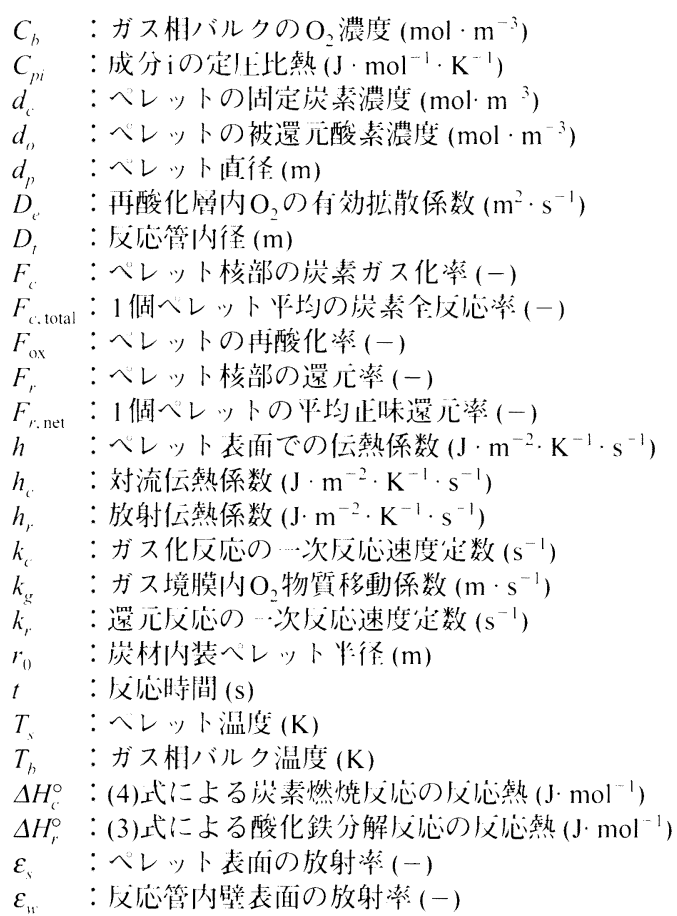

\section{文献}

1) J.Jimbo, Y.Miyagawa, M.Fujitomi, I.Kobayashi, T.Matsumura and M. Nishimura: Kohe Steel Eng. Rep.. 46 (1996). 14.

2 ) J.A.Lepinski: Proc. of Ironmaking Conf., Iron and Steel Society, Warrendale, (1993), 349.

3 ) Y.Miyagawa, T.Matsumura, Y.Takenaka, T.Sugiyama and T.Harada: CAMP-ISIJ, 10 (1997), 115.

4 ) Y.Miyagawa, Y.Takenaka, M.Shimizu and I.Kobayashi: CAMP-ISIJ, $10(1997), 116$

5 ) K.Miyagawa, T.Matsumura, Y.Takenaka, M.Shimizu, I.Kobayashi, T.Harada and D.Meisner: Proc. of 2nd Int. Cong. on Sci. Tech. of Ironmaking, Iron and Steel Society, Warrendale, (1998), 877.

6 ) J.Borlée and R.Munnix: Proc. of 2 nd Int. Cong. on Sci. Tech. of Ironmaking. Iron and Steel Society, Warrendale, (1998), 869.

7 ) B.H.Huang and W.-K.Lu: ISIJ Int., 33 (1993), 1055.

8 ) S.Sun and W.-K.Lu: ISIJ Int.. 33 (1993), 1062.

9 ) T.Sharma: Ironmaking Steelmaking, 19 (1992), 372.

10) S.N.Misra and R.C.Gupta: ISIJ Int.. 34 (1994), 468.

11) Y.Iguchi and R.Kamei: Tetsu-to-Hagané, 85 (1999), 439

12) O.Knacke and C.B.Alcock: Metallurgical Thermochemistry, 5th ed.. Pergamon Press, Oxford, (1979), 268.

13) X.-H.Chung, R.Takahashi and J.Yagi: Tetsu-to-Hagané, 81 (1995), 1043.

14) H.Mou and Y.Iguchi: Unpublished experimental result.

15）鉄徐製鍊，日本金属学会編，仙台。(1979), 66.

16) R.Bird, W.E.Stewart and E.N.Lightfoot: Transport Phenomena. John Wiley \& Sons Inc., New York, (1960), 409.

17) R.Takahashi, J.Yagi and Y.Omori: Bull. Res. Inst., Tohoku Unir'., 27 (1971) $586,175$.

18) S.Sugiyama and M.Hasatani: Chem. Eng. Jpn., 28 (1964), 355.

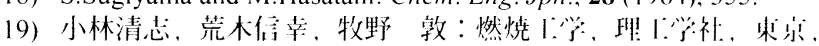
(1988), 123. 